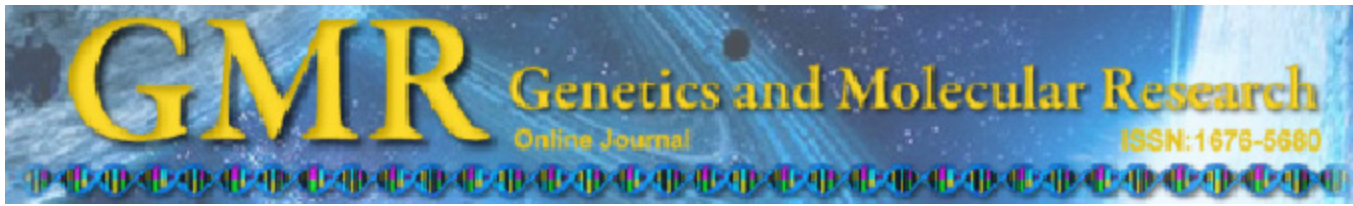

$\underline{\text { Review }}$

\title{
Polyploidy and epigenetic events in the evolution of Anura
}

\author{
M.L. Beçak \\ Laboratório de Genética, Instituto Butantan, São Paulo, SP, Brasil \\ Corresponding author: M.L. Beçak \\ E-mail:mlbecak@yahoo.com.br \\ Genet. Mol. Res. 13 (3): 5995-6014 (2014) \\ Received June 23, 2014 \\ Accepted July 27, 2014 \\ Published August 7, 2014 \\ DOI http://dx.doi.org/10.4238/2014.August.7.15
}

\begin{abstract}
This article reviews the polyploidy events that have long been demonstrated to play a role in the evolution of Anura, while also discussing the importance of epigenetic control of gene expression and diversity. Findings on Brazilian autopolyploid anurans, mainly of the genus Odontophrynus, obtained in previous studies on their cytogenetics, chromatin ultrastructure, and molecular gene regulation are discussed here. Our data on genome duplication and on epigenetic events were analyzed here regarding phylogenetic trees, including the classic $2 \mathrm{R}$ model for vertebrate evolution and the growing evidence of similar epigenetic mechanisms in animal and allopolyploid plants. We propose that polyploidy and epigenetic events led to rapid Anura diversity and speciation. Also, recent advances in molecular studies in other organisms led us to revisit some controversial models of evolution.
\end{abstract}

Key words: Anuran evolution; Genetic and epigenetic mutations; Autopolyploidy 


\section{Autopolyploidy as a driving force in anuran evolution}

An intriguing challenge for evolutionists is to explain how new and complex structures evolved in the course of evolution. Among the vertebrates, the emergence of amphibians from fishes during the late Devonian required anatomical and functional alterations necessary for terrestrial life. The Neo-Darwinism theory explains that these changes result from the accumulation of random mutations exposed to natural selection. Accordingly, intraspecific diversity would be a by-product of a gradual selective process of microevolution. Nevertheless, major interspecies alterations, which occurred in amphibian evolution, for example, may indicate the involvement of other mechanisms of macroevolution, leading to the creation of higher levels of organization as new genera, families, and phyla.

It is known that haploid DNA content ("genome size" or "C-value") is not associated with organism complexity. The findings of non-coding DNA, including "junk" DNA (pseudogenes) and selfish DNA (transposable elements), explained the differences in DNA content between species or other groups (Ohno, 1972; Doolittle and Sapienza, 1980). The data on genome sizes indicate great variability among animal groups (overall 130 -fold, from $1 \mathrm{C}=0.95$ to $120 \mathrm{pg}$ ) (Gregory, 2003). Morescalchi and Olmo (1982) estimated genome sizes and repetitive and nonrepetitive nucleotide fractions in some reptiles, amphibians, and selachians, and hypothesized that DNA variation reflects an adaptive role in the course of evolution of the amniotes.

The increase in DNA content in some species of anurans was demonstrated to result from autopolyploidy (Beçak et al., 1966, 1967b). This event led to the idea that the vertebrate genome evolved through two DNA duplications (2R), one in the transition of the invertebrates to the vertebrates, and the other in the divergence of the Osteichthyes (Ohno, 1970, 1999). Further molecular studies on Hox genes confirmed the occurrence of two polyploidizations and indicated that the second R occurred prior to the divergence of Osteichthyes (Postlethwait et al., 1998).

According to Ohno $(1970,1999)$, polyploidization provides the raw material for genome evolution through the production of gene redundancy. Later alterations of these copies would result in the acquisition of new functions and in speciation.

The idea that vertebrate evolution proceeded through polyploidizations was further confirmed by other molecular findings of paralogous genes in several gene families. Paralogous genes are related genes in the same species descendant from a genome duplication. Conversely, orthologous genes are related genes belonging to different species that descended from a speciation event.

Undoubtedly, random mutation and selection had a fundamental role in the creation of new species, as predicted in the Neo-Darwinism theory. This model of evolution assumes that mutations are random events with the same probability of occurring in natural populations. According to this idea, random mutations produce genetic differences whose frequencies would be the result of the selection of advantageous phenotypes. Despite its universal acceptance, this model of evolution is questioned regarding the way natural selection operates random mutations. The controversial idea dictated through molecular experiments assumes that nonrandom mutations could create new species. This model proposes that the genomes have already silenced polymorphisms that can reveal new phenotypes by chemicals or environmental changes (Waddington, 1942; Rutherford and Lindquist, 1998). Evidence favoring this hypothesis was presented by Rohner et al. (2013), showing that inhibition of the heat shock protein 90 (HSP 90) reveals silent polymorphisms of eye size in cavefish. This idea still remains an open question among Neo-Darwinists. 
Here, we suggest that in Anura, polyploidization followed by genetic and epigenetic events led to fast diversification. This idea does not depreciate the important role of natural selection operating in single mutations, and also does not conflict with the relevant involvement of tandem duplications creating DNA increase and diversity. It adds another perspective to explain how evolution operates.

\section{Phylogeny of the anurans}

A model for the origin and evolution of the amphibians was schematically traced by Ohno (1970). On the surface, the first amphibian Ichthyostega emerged from the Crossopterygian fish in the upper Devonian. Through a dichotomy, the Ichthyostega originated the Lepospondyls and Rachitomes in the Carboniferous and Permian periods. Modern anurans descended from the Rachitomes, while living Urodela and probably Gymnophiona descended from Lepospondyls (Figure 1).



Figure 1. Diagram indicating the origin of anurans, adapted from Ohno (1970). 
Another fundamental role of the Ichthyostega is that they originated the first reptile lineage, the Cotylosaurus, which evolved to Anapsida, Diapsida, and Synapsida. The Diapsida gave origin to Avis, Crocodilia, Lacertilia, and Ophidia. The Anapsida evolved into Chelonia and the Synapsida originated the mammals.

The model proposed by Morescalchi (1973) for the evolution of Amphibia was based on systematic and cytogenetic data and indicated that the recent amphibians, including Pelobatidae and higher Anura, may have originated from a Leptodactylid stock. Members of this stock had dispersed to different continents from the Gondwanaland at the end of Jurassic or afterwards (Figure 2).

Cytogenetic findings reported the occurrence of autopolyploid species in several Anura families (Figure 2 and Table 1) as well as several diploid related species (Table 2).



Figure 2. A schematic drawing showing the dispersion of Leptodactylid species in the Tertiary period. This event occurred before the Cretaceous, prior to the final breaking-up of the Gondwanian super-continent, based and modified from Morescalchi (1973) and complemented with further polyploidy descriptions. Time when polyploidy phenomena occurred is not determined. 


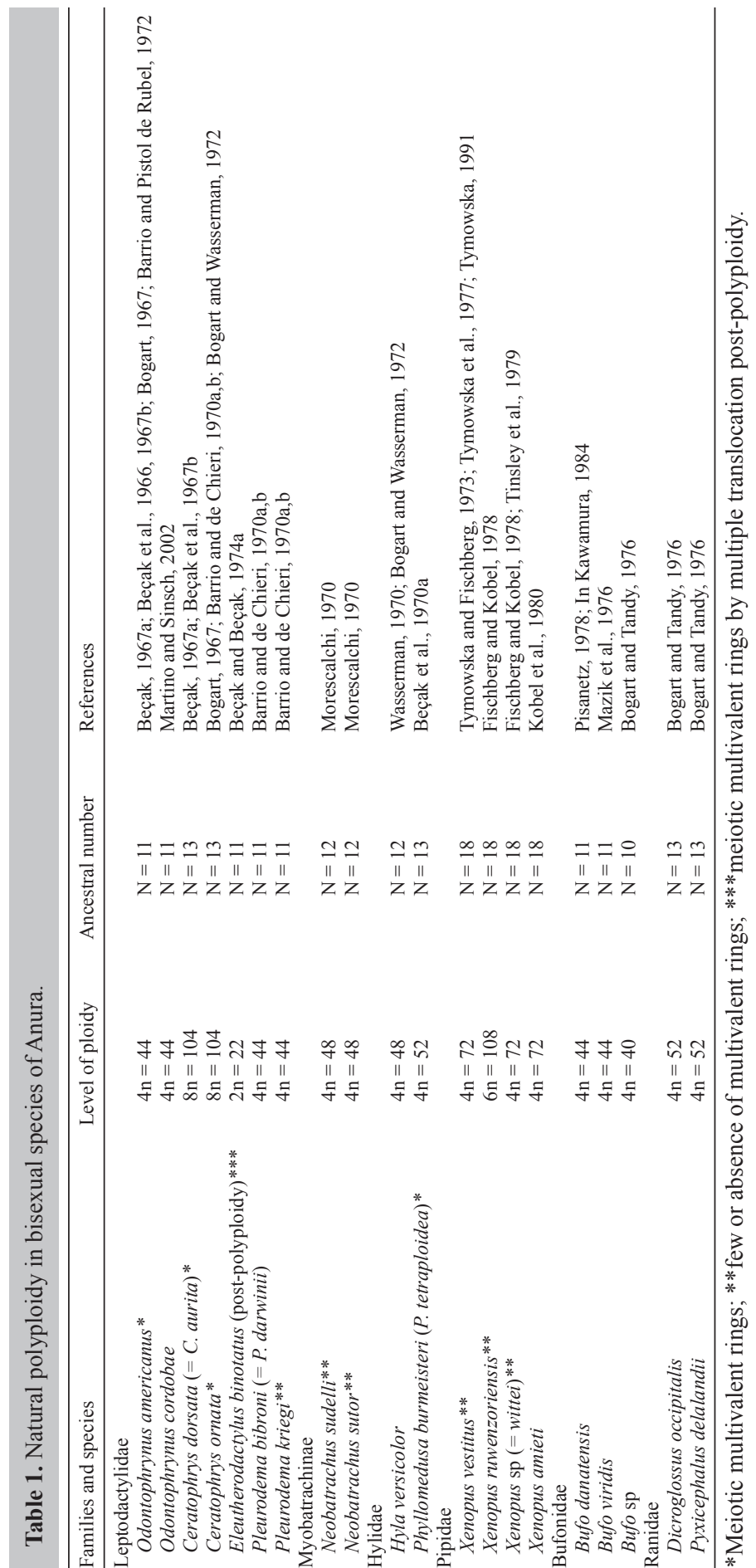




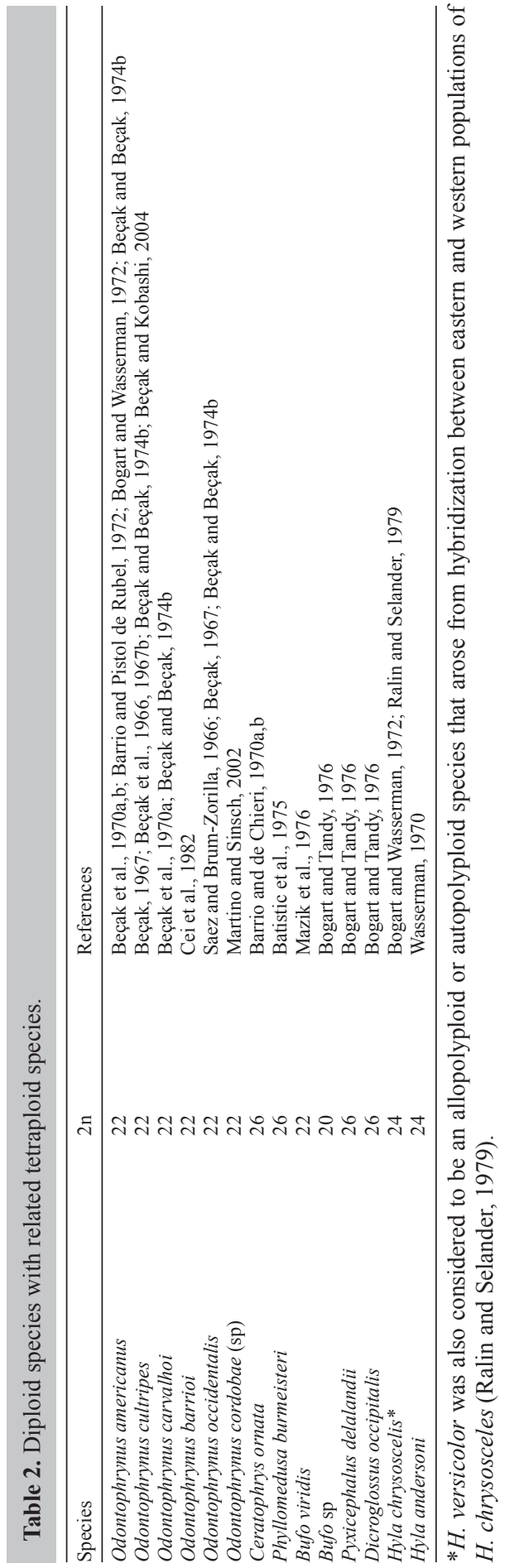


In the case of the family Pipidae, different levels of ploidy were found in the genus Xenopus from Africa. It is not known whether Xenopus fraseri $(2 \mathrm{n}=36)$, Xenopus amieti $(2 \mathrm{n}$ $=72)$ and Xenopus ruwenzoriensis $(2 \mathrm{n}=108)$ are auto- or allopolyploid species (Kobel et al., 1980; supplemented with previous references).

As pointed out by Martino and Sinsch (2002), the data on mitochondrial DNA in Hyla chrysoscelis/Hyla versicolor indicated that the tetraploid forms had multiple origins and that there are tetraploid lineages without related diploids (Ptacek et al., 1994; Mable and Roberts, 1997).

Figure 3 shows the geographical distribution of the species of the genus Odontophrynus (Beçak and Beçak, 1974b; supplemented with data from Ruiz et al., 1981, 1982, 1984; Barrio and Pistol de Rubel, 1972; Saez and Brum-Zorrilla, 1966). In these studies, the sympatry of both diploid and tetraploid specimens of Odontophrynus americanus was found in Santa Barbara do Sul, Brazil (Ruiz et al., 1984). The latter authors reported another map with the geographical distribution of $O$. americanus in Southern Brazil.

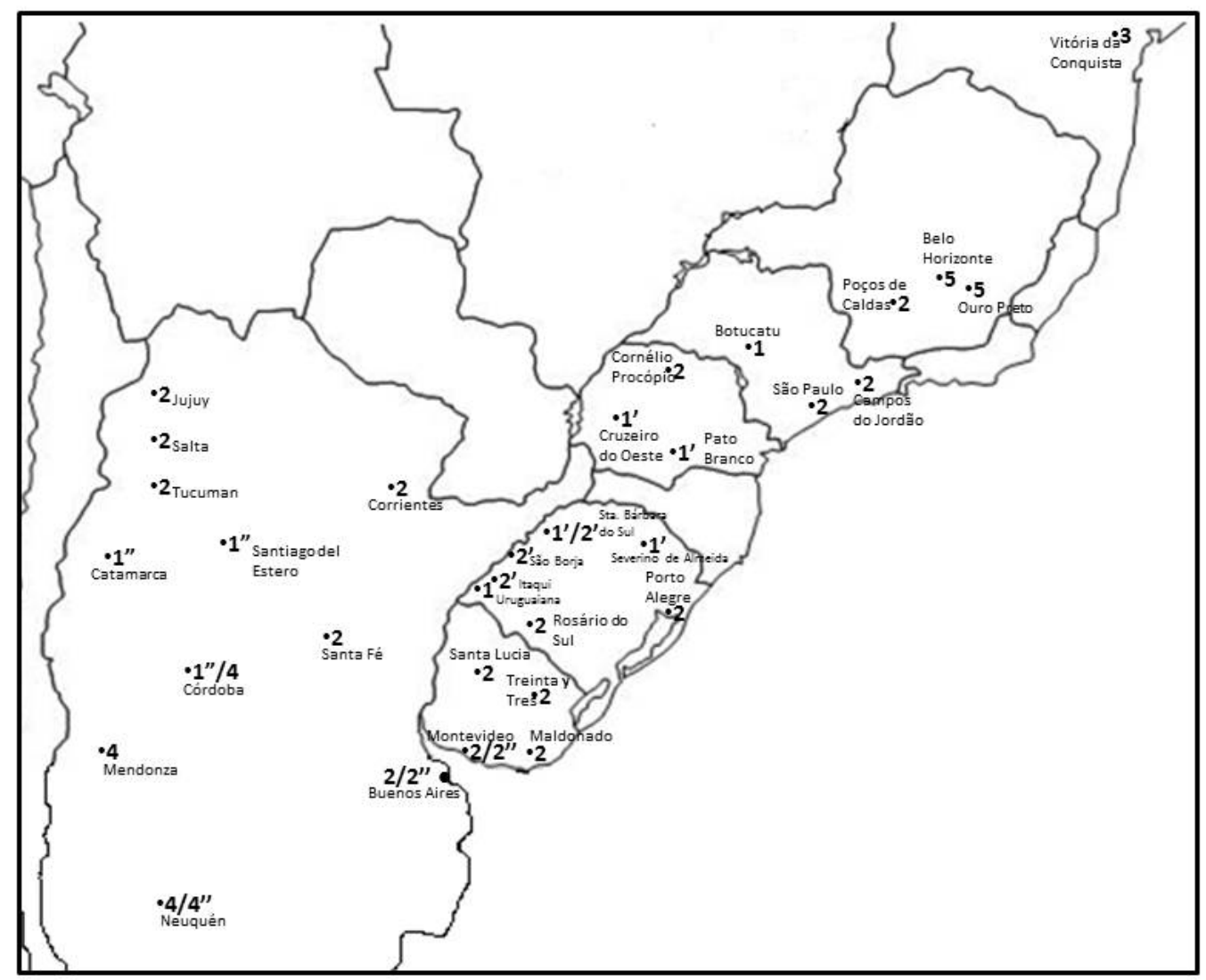

Figure 3. Geographical distribution of Odontophrynus species from several regions of Brazil, Uruguay and Argentina, as follows: 1) O. americanus, 2n; 2) O. americanus, 4n; 3) O. carvalhoi, 2n; 4) O. occidentalis, 2n; 5) O. cultripes, 2n. Beçak and Beçak, 1974b (1 to 5), Ruiz et al., 1984 (1' and 2'); Barrio and Pistol de Rubel, 1972 (1"); Saez and Brum-Zorrilla, 1966 (2"); Ruiz et al., 1982 (4”). 
Polyploidy in amphibians was also reviewed by Kawamura (1984). Although allopolyploidy occurred in plants and in parthenogenetic vertebrates, it was once believed that autopolyploidy would be incompatible with the sex-determination mechanisms in bisexual vertebrates (Muller, 1925). This assumption changed with the demonstration of autopolyploidy in bisexual anurans (Beçak, 1967a; Beçak et al., 1966, 1967b, 1970a; Beçak and Beçak, 1974a,b).

Although heteromorphic sex chromosomes are not commonly present in anurans, some cytogenetic studies have reported male and female heterogamety. Pyxicephalus adspersus has female heterogamety (ZZ/ZW) (Schmid, 1980; Schmid and Bachman, 1981); Eusophus migueli and Rana esculenta have male heterogamety (XX, XY) (Iturra and Veloso, 1981; Schempp and Schmid 1981, respectively).

\section{Intra- and interspecific chromosomal polymorphisms in Odontophrynus}

Several investigations have examined the polymorphisms of secondary constrictions (Table 3) and of C and NOR bands (Table 4) in species of South American Odontophrynus. Hypothetical phylogenies based on these polymorphisms were proposed to explain the evolution of this genus (Beçak and Beçak, 1974b; Ruiz and Beçak, 1976; Ruiz et al., 1980, 1981; Cortadas and Ruiz, 1988).

In accordance with the geographical distribution and the polymorphism of secondary constrictions, the karyotype having satellites in pair 11 (O. americanus, 2n; Odontophrynus cultripes, 2n; and Odontophrynus occidentalis, 2n) was assumed as basic (Figure 4).

An eventual translocation in $2 \mathrm{n} O$. americanus probably moved these satellites to pair 4. Further hybridization of this population could originate the karyotype with satellites in both pairs 4 and 11, as described by Beçak et al. (1974b). Duplication of this genome would originate the tetraploid population with satellites on the same pairs. A loss of the satellites on pair 4 could originate the tetraploid karyotype with satellites only on pair 11 .

Another suggestion also indicated that the $4 \mathrm{n}$ species with satellites on pairs 4 and 11 resulted from the hybridization of two $2 \mathrm{n}$ populations with different positions of the satellites. The presence of satellite in pair 8 of 2 n Odontophrynus carvalhoi was explained by an eventual translocation from pair 11 (Beçak and Beçak, 1974b).

On the basis of NOR banding, another phylogenetic line was assumed to explain the evolution and diversification of the genus Odontophrynus (Ruiz et al., 1981). This idea proposes that an original ancestor with satellites on pair 11 gave rise to the contemporary species. The authors also assumed the suggestion by Beçak and Beçak (1974b) that translocation may explain the appearance of satellites in chromosomes 4 and 8.

Chromosomal rearrangements as multiple translocations in post-polyploids occurred in Southern Brazil and Uruguay. These alterations, reducing the number of chromosomes, led to the diploidization process. Also, some cytogenetic polymorphisms at secondary constrictions (Beçak, 1969; Beçak and Beçak, 1974b) or in NOR bandings or C-bandings in O. americanus (Ruiz et al., 1980; 1981; Schmid et al., 1985; Almeida et al., 1986) and in Ceratophrys ornata (Schmid et al., 1985), as well as in Ceratophrys dorsata (Soares-Scott et al., 1988), have been interpreted as post-polyploid events.

Interspecific variability of DNA content has also been reported in Amphibia, including Odontophrynus species (Beçak et al., 1970a). 


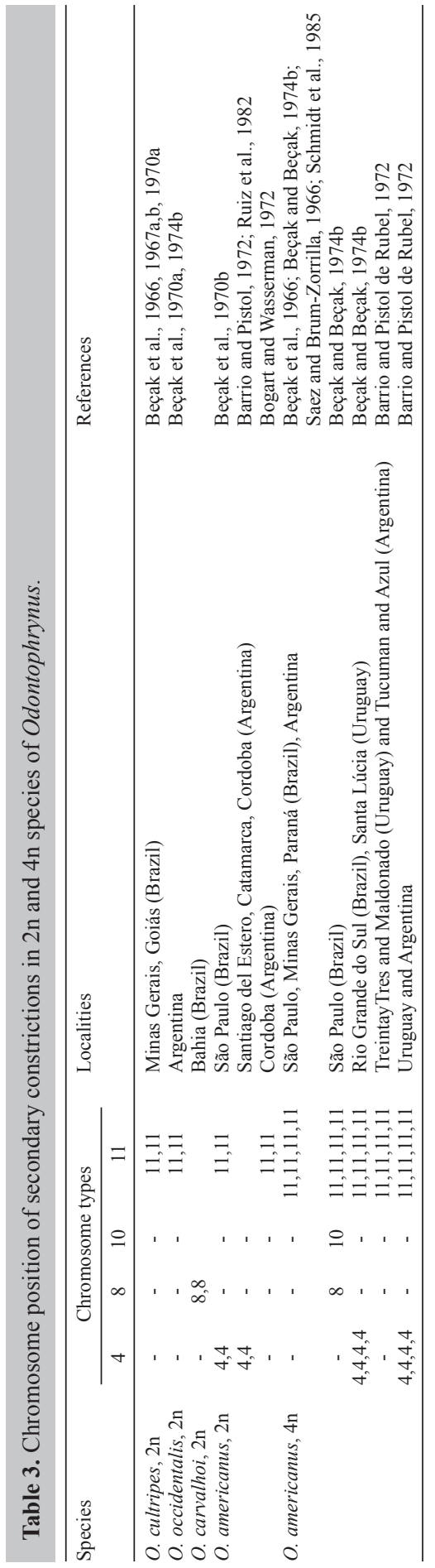




\section{Table 4. NOR position in $2 \mathrm{n}$ and $4 \mathrm{n}$ species of Odontophrynus.}

\begin{tabular}{|c|c|c|c|c|c|c|}
\hline \multirow[t]{2}{*}{ Species } & \multicolumn{4}{|c|}{ Chromosome types } & \multirow[t]{2}{*}{ Localities } & \multirow[t]{2}{*}{ References } \\
\hline & 4 & 8 & 9 & 11 & & \\
\hline O. cultripes, $2 \mathrm{n}$ & - & - & - & 11,11 & Minas Gerais (Brazil) & \multirow[t]{5}{*}{ Ruiz et al., 1982} \\
\hline O. occidentalis, $2 \mathrm{n}$ & - & - & - & $\begin{array}{l}11,11 \\
11,11\end{array}$ & Mendoza (Argentina) & \\
\hline O. carvalhoi, $2 \mathrm{n}$ & - & 8,8 & - & - & Bahia (Brazil) & \\
\hline \multirow[t]{4}{*}{ O. americanus, $2 \mathrm{n}$} & 4,4 & - & - & - & São Paulo (Brazil), Cordoba (Argentina) & \\
\hline & 4,4 & - & - & 11,11 & São Paulo (Brazil) & \\
\hline & 4,4 & - & - & - & Cassino, Friburgo (Brazil) & \multirow[t]{2}{*}{ Almeida et al., 1986} \\
\hline & 4,4 & - & - & 11,11 & Friburgo (Brazil) & \\
\hline \multirow[t]{4}{*}{ O. americanus, $4 \mathrm{n}$} & - & - & - & $11,11,11,11$ & São Paulo (Brazil) & \multirow[t]{3}{*}{ Ruiz et al., 1982} \\
\hline & 4 & - & - & $11,11,11,11$ & Montevideo and Salto Grande (Uruguay) & \\
\hline & $4,4,4,4$ & - & - & - & Salto Grande (Uruguay) & \\
\hline & - & - & - & $11,11,11,11$ & Argentina & Schmidt et al., 1985 \\
\hline
\end{tabular}

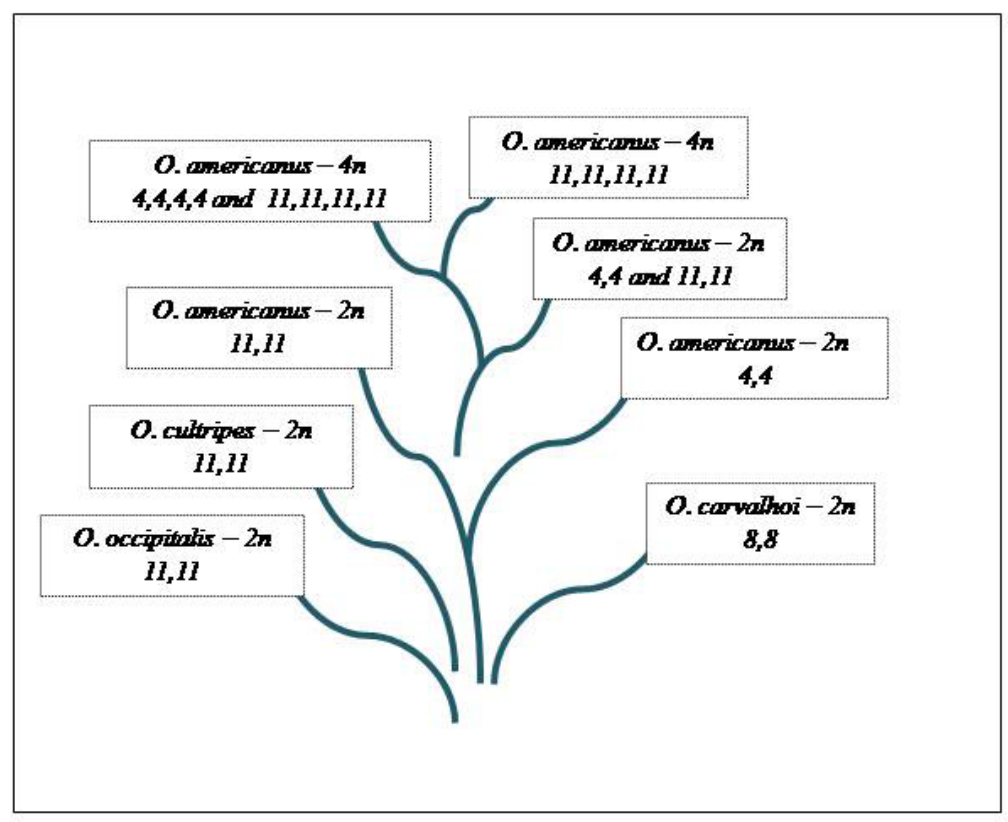

Figure 4. A suggestion to explain the evolution of Odontophrynus, based in the polymorphism of secondary constriction, according to the model by Beçak and Beçak, $1974 \mathrm{~b}$.

Besides polyploidy and translocations, other chromosome alterations have been observed in the anurans. In the family Leptodactylidae, the great interpopulation variation of the diploid number in Pseudopaludicola falcipes, with $2 \mathrm{n}=16,2 \mathrm{n}=18,2 \mathrm{n}=20$, and $2 \mathrm{n}=22$, was attributed to centric fusions (Beçak, 1967, 1968; Batistic, 1970). Fusion or fission of the centromeres accounted for the alterations between the karyotypes with $2 \mathrm{n}=16$ and $2 \mathrm{n}=18$. The higher diploid numbers $(2 n=20$ and $2 n=22)$ were explained by the probable occurrence of chromosome changes such as pericentric inversion or translocation after centric fusion (Batistic, 1970). Centric fusions were also described in Hylidae, with species having $2 n=22,2 n$ $=26,2 \mathrm{n}=30,2 \mathrm{n}=48$, and $2 \mathrm{n}=52$ chromosomes (Beçak, 1968; Rabello, 1970). 
Structural alterations of the genomes have also been observed in the post-polyploid anuran Eleutherodactylus binotatus, a diploid species $(2 \mathrm{n}=22)$ with 4 -fold DNA content and possessing a dodecavalent ring in the diplotene. These post-polyploid multiple translocations were interpreted as signals of diploidization (Ohno, 1970; Beçak and Beçak, 1974a). Translocation events detected through the presence of multivalent meiotic configurations also occurred in other anuran genus, Physalaemus petersi, 2n (Lourenço et al., 2000).

According to Morescalchi (1973), the more primitive karyotypes belonging to Ascaphids and Discoglossids contain acrocentric chromosomes and microchromosomes. Probably centric fusions occurred during evolution, reducing the chromosome number. The origin of the Pipidae is still controversial: this family is probably derived from primitive ascaphid forms (Morescalchi, 1973).

\section{Time of divergence of Amphibia}

Different methods have been used to estimate the time of divergence of vertebrates during the course of evolution. The paleontological data based on fossil records (Ohno, 1970) were compared with molecular clock results based on models of nucleotide or amino acid substitution (Hedges and Kumar, 2002). An interesting conclusion obtained from these molecular studies was that the molecular clock data to explain animal diversity agree with those of paleontological analysis of fossil records (Hedges and Kumar, 2002).

Analysis of the divergence time estimated using the molecular and fossil records of the Paleozoic and Cenozoic showed some differences regarding the origin of placental mammals. The results indicated that these animal groups originated before the Cretaceous and extinction of dinosaurs (Kumar and Hedges, 1998).

A new method was recently developed using DNA markers to estimate divergence time during evolution (Pennisi, 2013b). The data obtained showed that turtles are closer to crocodiles and birds than to lizards and snakes. This conclusion disagrees with Ohno's suggestion (1970) that turtles (descendants of Anapsida) diverged in time from crocodiles, alligators, lizards, snakes, and birds (descendants of Diapsida) in the early Triassic of the Mesozoic Era.

According to Gould (1995) and Ohno (1996, 1997), with the exception of Porifera and Coelenterata, almost all phyla appeared simultaneously within a 6 to 10 million-year window in the 550-million year Cambrian period. This great detonation of diversity is known as the Cambrian Explosion. According to Gould (1995), the Cambrian Explosion indicates the abrupt formation of the animal kingdom, in which all the structural archetypes arose during the same period.

Regarding the origin of present day amphibians, there are relatively scarce phylogenetic studies, because there is an evolutionary gap of fossils in the Mesozoic Era. Studies based on comparative DNA content showed that the Urodela as well as some Anura and Apoda have high DNA content. Great variations in nuclear DNA quantity were described between species of a single family as well as between families. Some interspecific differences in nuclear DNA content were attributed to polyploidy (Beçak et al., 1967b; Morescalchi, 1973).

The time when polyploidy occurred among Anura species is not known. Considering the high frequency of quadrivalent and octovalent chromosomes in meiosis of the $4 \mathrm{n} O$. americanus and Phyllomedura burmeisteri ( $=$ P. tetraploidea sp) and in the $8 \mathrm{n} \mathrm{C.} \mathrm{dorsata,} \mathrm{it}$ seems that polyploidization in these species was a more recent event compared to other polyploid species. 
By to the time when tetraploidy occurred, studies of $\alpha$ - and $\beta$-globin sequences indicated that the diversification of Xeropus laevis and Xeropus tropicalis happened at 110-120 million years ago (MYA). Moreover, a probable duplication of the X. laevis genome occurred at 40-60 MYA (Knöchel, 1994). These conclusions are based on previous data showing that $X$. leavis is a probable tetraploid $(2 \mathrm{n}=36)$, having two clusters of $\alpha$ - and $\beta$-globin genes, while $X$. tropicalis $(2 \mathrm{n}=20)$ has only one cluster (Jeffreys et al., 1980; Hosbach et al., 1983).

To study the level of diversity among diploid and tetraploid species, we performed interspecific mating of $O$. americanus $(4 \mathrm{n})$ with several $2 \mathrm{n}$ species of the same genus. Artificial triploid $(3 \mathrm{n}=33)$ hybrids were obtained from Odontophrynus by the mating of $4 \mathrm{n} O$. americanus females with $2 \mathrm{n}$ males of $O$. americanus, $O$. cultripes and $O$. carvalhoi (Beçak et al., 1968a; Beçak and Beçak, 1970b). The observations in meiosis that $3 \mathrm{n}$ produces $\mathrm{n}, 2 \mathrm{n}$ and $3 \mathrm{n}$ gametes and aneuploids led the authors to assume that $3 \mathrm{n}$ may be a stepping stone for the production of different ploidy levels (Beçak and Beçak, 1970) (Tables 5 and 6). This assumption later found support on the description of $3 \mathrm{n}$ allopolyploids in populations of $P$. burmeisteri (= P. tetraploidea $\mathrm{sp})$ (Haddad et al., 1994).

Table 5. Induced polyploid hybrids in intra- and interspecific mating.

\begin{tabular}{|c|c|c|c|c|}
\hline \multicolumn{3}{|c|}{ Species } & \multicolumn{2}{|r|}{ Authors } \\
\hline $\begin{array}{l}\text { O. americanus } \\
\text { }(4 \mathrm{n}) \\
\text { São Paulo - Brazil }\end{array}$ & $\begin{array}{l}\text { O. cultripes } \\
x \bigcirc(2 \mathrm{n}) \\
\text { Minas Gerais - Brazil } \\
\mathrm{F}_{1}: \text { viable (up to } 5 \text { years old) } \\
3 \mathrm{n}=33 \\
\text { (spermatocytes with III, II, I configurations) }\end{array}$ & $\begin{array}{l}\text { O. americanus } \\
\mathrm{x}^{n}(2 \mathrm{n}) \\
\text { São Paulo - Brazil } \\
\mathrm{F}_{1}: \text { viable } 3 \mathrm{n}=33 \\
\mathrm{x}(2 \mathrm{n}) \\
\text { Montevideo (Uruguay) } \\
\mathrm{F}_{1}: \text { viable } 6 \mathrm{n}=66\end{array}$ & $\begin{array}{l}\text { O. carvalhoi } \\
x \bigcirc(2 \mathrm{n}) \\
\text { Bahia - Brazil } \\
\mathrm{F}_{1}: \text { viable } 3 \mathrm{n}=33\end{array}$ & $\begin{array}{l}\text { Beçak et al., 1968a } \\
\text { Beçak et al., 1970b } \\
\text { Beçak and Beçak, } 1970 \\
\text { Ruiz et al., } 1981\end{array}$ \\
\hline $\begin{array}{l}\text { O. americanus } \\
\partial(4 \mathrm{n}) \\
\text { São Paulo - Brazil }\end{array}$ & $\begin{array}{l}\text { O. cultripes } \\
\mathrm{x}_{+}(2 \mathrm{n}) \\
\text { Minas Gerais - Brazil } \\
\mathrm{F}_{1}: \text { unviable } 3 \mathrm{n} \\
\text { (postgastrula stage) }\end{array}$ & $\begin{array}{l}\text { O. americanus } \\
\mathrm{x}_{+}(2 \mathrm{n}) \\
\text { São Paulo - Brazil } \\
\mathrm{F}_{1}: \text { unviable } 3 \mathrm{n}\end{array}$ & & $\begin{array}{l}\text { Beçak et al., 1968a } \\
\text { Beçak et al., 1970b } \\
\text { Beçak and Beçak, } 1970\end{array}$ \\
\hline
\end{tabular}

Table 6. Natural polyploid hybrids from interspecific mating.

\begin{tabular}{|c|c|c|}
\hline \multicolumn{2}{|c|}{ Species } & \multirow{2}{*}{$\begin{array}{l}\text { Authors } \\
\text { Ruiz et al., } 1980\end{array}$} \\
\hline O. americanus & O. cultripes & \\
\hline$(4 n)$ & x (unknown sex) (2n) & \\
\hline Minas Gerais - Brazil & $F_{1}: 1$ viable young $3 n=33$ & \\
\hline P. burmeisteri & P. distincta & Haddad et al., 1994 \\
\hline (= tetraploidea $)$ & x (unknown sex) (2n) & \\
\hline$(4 \mathrm{n})$ & $\mathrm{F}_{1}: 7$ viable $3 \mathrm{n}$ (with III, II, I configurations) & \\
\hline São Paulo - Brazil & & \\
\hline
\end{tabular}

\section{Epigenome: epigenetic control of genome expression}

Epigenetic events are mechanisms that allow different expression of the genome in different cells and stages of development without change in the original DNA sequences. The variation of gene expression is caused by molecular mechanisms such as methylation of cytosine residues, histone modification, and non-protein coding RNA (ncRNA). The mechanisms of epigenetic control constitute the epigenome. 


\section{Methylation signals}

Ongoing biochemical studies indicate that the steps in animal development are controlled by genetic and epigenetic signals. Epigenetic marks are those that are inheritable without DNA sequence alteration. These signals identify active and silenced genes. DNA methylation and histone alterations are epigenetic marks.

It is known that DNA methylation signals are erased in the initial steps of development and a de novo methylation pattern is restored during implantation (Hashimshony et al., 2003). In animal cells, DNA methylation can account for epigenetic silencing of gene activity through chromatin condensation. Higher order chromatin fibers contain inactive genes. Conversely, open chromatin fibers unfolded into nucleosomes display active DNA sequences. Chromosome regions with condensed heterochromatin contain a low density of active genes and high levels of transposons and repeats. It was also pointed that DNA methylation is required to prevent DNA damage caused by transposons (Yoder et al., 1997).

The presence of methyl groups is now accepted to be necessary for chromatin condensation and gene silencing. In the chromosomes, the methyl group binds preferentially to $\mathrm{H}_{1}$ histone (Jost and Hofsteenge, 1992), which is associated with the DNA linker between nucleosomes. The condensed chromatin fibers characterize the heterochromatic regions of the chromosomes. Histones $\mathrm{H}_{3}$ and $\mathrm{H}_{4}$ are mostly hypoacetylated in these heterochromatic regions, which carry silenced genes (Hashimshony et al., 2003).

Furthermore, regulatory proteins were found to bind preferentially to DNA palindromes (Mezquita et al., 1985). Long palindromes formed by smaller ones were found in the amino and carboxyl terminal regions of $\mathrm{H}_{1}$ belonging to five species of vertebrates (trout, chicken, human, rat, and mouse) (Ohno and Beçak, 1993).

Relatively few investigations of chromatin structure have been performed in lower vertebrates. Comparative studies evidenced that in snakes and in the tetraploid anuran $O$. americanus, the chromatin fibers from spermatocytes I have a similar appearance as the ones of mammalian spermatocytes in regard to nucleosomes and higher order structures (Beçak et al., 1977).

An epigenetic aspect found in $O$. americanus $4 \mathrm{n}$ was the occurrence of amphiplasty, characterized by diphasic stages of the cell cycle revealed in the two halves of the genomes. This phenomenon may indicate differences in the DNA replication time, probably related to methylation (Beçak and Beçak, 1998). Epigenetic mechanisms silencing extra copies of genes were also proposed (Schmidtke et al., 1976; Ruiz et al., 1989; Beçak and Kobashi, 2004 for review).

Comparative studies using autoradiography demonstrated that, although there were differences in satellite replication time between the parental chromosomes of triploid interspecific hybrids, asynchronous DNA replication did not occur in tetraploids (Batistic et al., 1973).

Structural studies using restriction-enzyme banding in Odontophrynus (Beçak et al., 1988; Beçak and Kobashi, 2004 for review) suggested that the difficulty in obtaining G-bands in anurans would be caused by the lower number of CG sequences (probably arranged in small agglomerations) or due to higher chromatin packing, as previously proposed (Schmid, 1978; Birstein, 1982; Bernardi et al., 1985; Schmid and de Almeida, 1988).

In the anuran $O$. americanus, pioneer papers reported that genetic variability of autopolyploidy specimens results from the tetrasomic expression of the duplicated alleles. Indeed, in comparing the expression of homologous genes in natural autopolyploid specimens of $O$. americanus with the diploid ones, research indicated that the electrophoretic patterns 
of several enzymes exhibit three phenotypes in diploids, while there are five in tetraploids, as expected by Hardy-Weinberg $(\mathrm{p}+\mathrm{q})^{4}$ (Beçak et al., 1968b; Schwantes et al., 1969, 1976, 1977).

The tetrasomic expression of the duplicated alleles and the silencing of extra copies in the tetraploids support the further "subfunctional" model that partitioning of ancestral functions among duplicated copies may occur after genome doubling (Lynch and Conery, 2000, Adams et al., 2003).

Previous experiments were performed to clarify whether or not the greater genetic variability observed in the $4 \mathrm{n}$ species resulted from the redundant copies or from gene regulation. Accordingly, it was shown that in $2 \mathrm{n}$ and $4 \mathrm{n} O$. americanus, autotetraploidy does not result in doubling total RNA content (Beçak and Goissis, 1971), even though 4n have twice the number of $18 \mathrm{~S}$ and $28 \mathrm{~S}$ ribosomal genes (Schmidtke et al., 1976). Furthermore, the quantitative synthesis of lactate dehydrogenase and hemoglobin has been demonstrated to be reduced in $4 \mathrm{n}$ O. americanus, being similar to what had been found in 2n species (Beçak and Pueyo, 1970). This was confirmed by data obtained using NOR studies (Ruiz et al., 1981).

It was stated that the reduced genetic activity in the tetraploid could be at the transcriptional level, probably by methylation of rDNA (Ruiz and Brison, 1989). This hypothesis was further supported by data on erythropoiesis and on the transcription of DNA coding for hemoglobin in $2 \mathrm{n}$ and $4 \mathrm{n} O$. americanus, which revealed that the $4 \mathrm{n}$ cells have only $30 \%$ more hemoglobin and 25-30\% more ribosomes than do $2 \mathrm{n}$ cells (Cianciarullo et al., 2000).

Besides the analysis of chromatin structure, it was also observed in electron microscopic studies that the reduced transcription activity of the $4 \mathrm{n}$ specimens, when compared to the $2 \mathrm{n}$, may be the result of either the lower number of nuclear pore complexes (NPC) in the tetraploids or changes in the transport of products to the cytoplasm (Maul et al., 1980). Along the same line of investigation, further electron microscopic description of complex aggregates of neighboring NPCs in the $4 \mathrm{n}$ species indicated a phenotype of low metabolic activity (Beçak and Fukuda-Pizzocaro, 2007).

Comparative studies in diploid Hyla chrysoscelis and tetraploid H. versicolor (Bachmann and Bogart, 1975) revealed that the mechanism of gene regulation is similar to that found for $2 \mathrm{n}$ and $4 \mathrm{n}$ Odontophrynus.

Recently, several reports claimed that epigenetic mechanisms account for alterations of gene expression in human cells through chemical modifications of the histones by either methylation, acetylation or phosphorylation (Furey and Sethupathy, 2013; Kasowski et al., 2013; Kilpinen et al., 2013).

Rapid genome changes after polyploidy were demonstrated to occur in molecular experiments using synthetic polyploids of Brassica (Song et al., 1995). It was suggested that these genome alterations could accelerate the process of evolution. The data obtained also showed that alterations in DNA methylation may account for genome changes. Also, in plants, fast alteration of flowering time due to methylation changes was reported in Arabidopsis thaliana (Pennisi, 2013a). Curiously, they observed that the new phenotypes were transmitted through eight generations of this plant.

\section{Transposable element (TE) signals}

Molecular experiments have demonstrated that eukaryote genomes display only a fraction of protein-coding DNA. The human genome with 3 billion DNA bases has only 
21,000 structural genes. Two-thirds of the human genome consists of TEs, which can move throughout the genome (Lorenc and Makalowski, 2003). TEs are considered to originate from virus insertion (Ovchinnikov et al., 2002). They were first named "parasites" or "selfish" DNA because of their ability to out-replicate independently and for being considered unnecessary DNA to hosts (Doolittle and Sapienza, 1980).

The first reports showing that DNA amount does not correlate with organism complexity (the C-value paradox) led to the previous assumption of "junk" DNA, without function and considered to be "remains of extinct genes" (Ohno, 1972).

Accumulating evidence obtained from molecular studies shows that TEs are epigenetic marks involved in alterations of gene expression without changes of DNA sequences. Now they account for important roles regarding gene regulation and protein diversification, driving rapid species divergence (Makalowsky et al., 1994; Nekrutenko and Li, 2001; Ovchinnikov et al., 2002; Fedoroff, 2012). In plants with high DNA content, species divergence seems to be caused by TEs. Fedoroff (2012) pointed out that speciation in plants is a consequence of TE activation caused by DNA damaging agents, interspecific hybridization, and allopolyploidization. Conversely, it was proposed that the insertion of retroviral DNA in host genome may affect the control of RNA transcription and splicing, and could be either deleterious or useful to the host (Weiss and Stoye, 2013).

Recently, comparative studies of the mechanism in dosage compensation in Drosophila melanogaster, D. pseudoobscura and D. miranda demonstrated that two waves of TE amplification allowed the evolution of dosage compensation in neo-X-chromosomes (Ellison and Bachtrog, 2013; Chuong and Feschotte, 2013).

In the case of anurans, experiments on the molecular organization of $\alpha$-globin genes in $2 \mathrm{n}$ and $4 \mathrm{n}$ species of $O$. americanus revealed that intron 2, which is usually found in vertebrates, is absent in both cases, indicating that these sequences may be pseudogenes related to retrotransposition (Acedo et al., 1997). Yet, analysis of ribosomal intergenic spacers (IgSs) demonstrated a high level of amplification of these regulatory sequences in the $4 \mathrm{n}$ anurans, and that probably a transposon-like sequence was inserted in these IgSs during evolution (Alvares et al., 1998).

\section{CONCLUSION}

Here, we discuss our data on cytogenetic and population studies dealing with the evolution of the anurans while also focusing on molecular biology data obtained from other organisms.

Among the anurans, the genus Odontophrynus is a pivotal reference for understanding the diversification of the species. Population studies using cytogenetic and phylogenetic data showed that polyploidy had a fundamental role in the process of speciation. Moreover, the detection of post-polyploid alterations, such as multitranslocations, indicated how genome evolution has proceeded in different families after genome duplication. Also, molecular studies on gene regulation of hemoglobin, several enzymes, and ribosomal RNA have demonstrated that methylation is an effective epigenetic factor, silencing half of the duplicated genome and equalizing gene activity of $2 \mathrm{n}$ and $4 \mathrm{n}$ species.

The central dogma of biological evolution according to the Neo-Darwinism theory establishes that the accumulation of random mutations causes differences among organisms which will be exposed to natural selection. Nevertheless, variability and speciation in an- 
urans by genome duplication modulated by genetic and epigenetic events poses the validity of a complementary mechanism of evolution. Indeed, polyploidization and epigenetic events diverge from the classic conviction that variability is due only to the concatenated process: coding DNA sequences $\rightarrow$ mRNAs $\rightarrow$ proteins.

Our assumption is based on several approaches dealing with the level of gene expression of either rDNA, several enzymes, or hemoglobin comparatively analyzed in diploid and tetraploid species of anurans. It was assumed that the reduced expression of these genes detected in the tetraploid species was caused by methylation silencing of half of their genomes. Also, the tetrasomic gene expression determined in the tetraploids indicated post-polyploid diversification. This idea is supported by the subfunctionalization model proposed for allopolyploid plants. Moreover, the identification of pseudogenes and remains of TEs in ribosomal genes indicated that these signals had a role in promoting gene variability after polyploidy.

This scenario poses the conclusion that polyploidy modulated by genetic and epigenetic agents has been a dynamic force driving rapid variability among anurans.

This assumption is supported by emerging data in Brassica and Arabidopsis allopolyploid plants, indicating that genetic and epigenetic events stabilize duplicated genomes (Comai et al., 2000; Pikaard, 2001; Lee and Chen, 2001).

Current researchers propose that alterations of gene activity without changes in DNA sequences can be inheritable in animal evolution. Rohner et al. (2013) showed that alterations in HSP 90 can reveal silenced polymorphisms in cavefish. This means that masked polymorphisms present in genomes could reveal new phenotypes by stress created by environmental changes. The advantageous traits would be positively selected. Along the same line, Skinner (2014) proposes that "transgeneration epigenetics" occurs in rats.

In the meantime, whether epigenetic mutations are really heritable or not remains to be determined and demand further studies.

\section{ACKNOWLEDGMENTS}

Thanks go to Willy Beçak for the critical reading of the manuscript, Carolina Sabino for the excellent editorial assistance and Carlos Roberto de Paula Leão for the English revision.

\section{REFERENCES}

Acedo MDP, Paranhos-Baccolã G, Denoya CD and Ruiz IRG (1997). Molecular cloning of exons II and III of the ALPHAglobin major gene from Odontophrynus americanus 2n and 4n (Amphibia-Anura). Braz. J. Genet. 20: 613-617.

Adams KL, Cronn R, Percifield R and Wendel JF (2003). Genes duplicated by polyploidy show unequal contributions to the transcriptome and organ-specific reciprocal silencing. Proc. Natl. Acad. Sci. U. S. A. 100: 4649-4654.

Almeida TMB, Ruiz ITG and Beçak W (1986). Ribosomal gene activity detected by silver staining in two diploid populations of Odontophrynus americanus (Amphibia, Anura) from Southern Brazil. Rev. Bras. Genet. 9: 433-437.

Alvares LE, Brison O and Ruiz IR (1998). Identification of enhancer-like elements in the ribosomal intergenic spacer of Odontophrynus americanus $2 \mathrm{n}$ and $4 \mathrm{n}$ (Amphibia, Anura). Genetica 104: 41-44.

Bachmann K and Bogart JP (1975). Comparative cytochemical measurements in the diploid-tetraploid species pair of hylid frogs Hyla chrysoscelis and H. versicolor. Cytogenet. Cell Genet. 15: 186-194.

Barrio A and de Chieri RP (1970a). Relaciones cariosistematicas de los Ceratophrydidae de la Argentina Amphibia, Anura. Physis 30: 321-329.

Barrio A and de Chieri RP (1970b). Estudios citogenéticos sobre el género Pleurodema y sus consecuencias evolutivas (Amphibia, Anura, Leptodactylidae). Physis 30: 309-319.

Barrio A and Pistol de Rubel D (1972). Encuesta cariotípica de problaciones argentino-uruguayas de Odontophrynus 
americanus (Anura, Leptodactylidade) relacionada com otros rasgos taxonômicos. Physis 31: 281-291.

Batistic RF (1970). Estudo Cromossômico e Mecanismos de Especiação em Pseudopaludicola (Leptodactylidae - Anura). Master's thesis. Departamento de Biologia. Instituto de Biociências, Universidade de São Paulo, São Paulo.

Batistic RF, Beçak W and Beçak ML (1973). DNA autoradiographic patterns in diploid, triploid and tetraploid amphibians (Ceratophrydidae). Cytologia 38: 687-697.

Batistic RF, Soma M, Beçak ML and Beçak W (1975). Further studies on polyploid amphibians. A diploid population of Phyllomedusa burmeisteri. J. Hered. 66: 160-162.

Beçak ML (1967a). Cariótipos e Evolução Cromossômica em Amphibia, Anura. Doctoral thesis. Faculdade de Medicina de Ribeirão Preto, Universidade de São Paulo, Ribeirão Preto.

Beçak ML (1968). Chromosomal analysis of eighteen species of Anura. Caryologia 21: 191-208.

Beçak ML and Beçak W (1970). Further studies on polyploid amphibians (Ceratophrydidae). 3. Meiotic aspects of the interspecific triploid hybrid: Odontophrynus cultripes $(2 \mathrm{n}=22)$ x O. americanus $(4 \mathrm{n}=44)$. Chromosoma 31: 377 385.

Beçak ML and Beçak W (1974a). Diploidization in Eleutherodactylus (Leptodactylidae-Amphibia). Experientia 30: 624625.

Beçak ML and Beçak W (1974b). Studies on polyploidy amphibians - karyotype evolution and phylogeny of the genus Odontophrynus. J. Herpetol. 8: 337-341.

Beçak ML and Beçak W (1998). Evolution by polyploidy in Amphibia: new insights. Cytogenet. Cell Genet. 80: 28-33.

Beçak ML and Kobashi LS (2004). Evolution by polyploidy and gene regulation in Anura. Genet. Mol. Res. 3: 195-212.

Beçak ML and Fukuda-Pizzocaro K (2007). Pore-linked filaments in anura spermatocyte nuclei. An. Acad. Bras. Cienc. 79: 63-70.

Beçak ML, Beçak W and Rabello MN (1966). Cytological evidence of constant tetraploidy in the bisexual South American frog Odontophrynus americanus. Chromosoma 19: 188-193.

Beçak ML, Beçak W and Rabello MN (1967a). Further studies on polyploid amphibians (Ceratophrydidae). I. Mitotic and meiotic aspects. Chromosoma 22: 192-201.

Beçak ML, Denaro L and Beçak W (1970a). Polyploidy and mechanisms of karyotypic diversification in Amphibia. Cytogenetics 9: 225-238.

Beçak ML, Beçak W and Vizotto LD (1970b). A diploid population of the polyploid amphibian Odontophrynus americanus and an artificial intraspecific triploid hybrid. Experientia 26: 545-546.

Beçak ML, Fukuda K and Carneiro SM (1977). Chromatin ultrastructure of lower vertebrates. Experientia 33: 1314-1316.

Beçak ML, Stocco dos Santos RC, Soares-Scott MD, Batistic RF, et al. (1988). Chromosome structure in man and Amphibia-Anura, restriction enzymes. Rev. Bras. Genet. 11: 939-948.

Beçak W (1969). Genic action and polymorphism in polyploid species of amphibians. Genetics 61: (Suppl)-90.

Beçak W and Pueyo MT (1970). Gene regulation in the polyploid amphibian Odontophrynus americanus. Exp. Cell Res. 63: 448-451.

Beçak W and Goissis G (1971). DNA and RNA content in diploid and tetraploid amphibians. Experientia 27: 345-346.

Beçak W, Beçak ML, Lavalle D and Schreiber G (1967b). Further studies on polyploid amphibians (Ceratophrydidae). II. DNA content and nuclear volume. Chromosoma 23: 14-23.

Beçak W, Beçak ML and de Langlada FG (1968a). Artificial triploid hybrids by interspecific mating of Odontophrynus (Amphibia, Anura). Experientia 24: 1162-1164.

Beçak W, Schwantes AR and Schwantes ML (1968b). Polymorphism of albumin-like proteins in the South American tetraploid frog Odontophrynus americanus (Salientia: Ceratophrydidae). J. Exp. Zool. 168: 473-475.

Bernardi G, Olofsson B, Filipski J, Zerial M, et al. (1985). The mosaic genome of warm-blooded vertebrates. Science 228: 953-958.

Birstein VJ (1982). Structural characteristics of genome organization in amphibians: differential staining of chromosomes and DNA structure. J. Mol. Evol. 18: 73-91.

Bogart JP (1967). Chromosomes of the South American amphibian family Ceratophridae with a reconsideration of the taxonomic status of Odontophrynus americanus. Can. J. Genet. Cytol. 9: 531-542.

Bogart JP and Wasserman AO (1972). Diploid-polyploid cryptic species pairs: a possible clue to evolution by polyploidization in anuran amphibians. Cytogenetics 11: 7-24.

Bogart JP and Tandy M (1976). Polyploid amphibians: three more diploid-tetraploid cryptic species of frogs. Science 193: 334-335.

Cei JM, Ruiz IRG and Beçak W (1982). Odontophrynus barrioi, a new species of anuran from Argentina. J. Herpetol. 16: $97-102$.

Chuong EB and Feschotte C (2013). Transposons up the dosage. Science 342: 812-813.

Cianciarullo AM, Naoum PC, Bertho AL, Kobashi LS, et al. (2000). Aspects of gene regulation in the diploid and tetraploid 
Odontophrynus americanus (Amphibia, Anura, Leptodactylidae). Gen. Mol. Biol. 23: 357-364.

Comai L, Tyagi AP, Winter K, Holmes-Davis R, et al. (2000). Phenotypic instability and rapid gene silencing in newly formed Arabidopsis allotetraploids. Plant Cell 12: 1551-1568.

Cortadas J and Ruiz IR (1988). The organization of ribosomal genes in diploid and tetraploid species of the genus Odontophrynus (Amphibia, Anura). Chromosoma 96: 437-442.

Doolittle WF and Sapienza C (1980). Selfish genes, the phenotype paradigm and genome evolution. Nature 284: 601-603.

Ellison CE and Bachtrog D (2013). Dosage compensation via transposable element mediated rewiring of a regulatory network. Science 342: 846-850.

Fedoroff NV (2012). Presidential address. Transposable elements, epigenetics, and genome evolution. Science 338: 758-767.

Fischberg M and Kobel HR (1978). Two new polyploid Xenopus species from western Uganda. Experientia 34: 10121014.

Furey TS and Sethupathy P (2013). Genetics. Genetics driving epigenetics. Science 342: 705-706.

Gould SJ (1995). Of it, not above it. Nature 377: 681-682.

Gregory TR (2003). Variations across amphibian species in the size of the nuclear genome supports a pluralistic, hierarchical approach to the C-value enigma. Biol. J. Linnean Soc. 79: 329-339.

Haddad CFB, Pombal JP and Batistic RF (1994). Natural hybridization between diploid and tetraploid species of leaffrogs, genus Phyllomedusa (Amphibia). J. Herpetol. 28: 425-430.

Hashimshony T, Zhang J, Keshet I, Bustin M, et al. (2003). The role of DNA methylation in setting up chromatin structure during development. Nat. Genet. 34: 187-192.

Hedges SB and Kumar S (2002). Genomics. Vertebrate genomes compared. Science 297: 1283-1285.

Hosbach HA, Wyler T and Weber R (1983). The Xenopus laevis globin gene family: chromosomal arrangement and gene structure. Cell 32: 45-53.

Iturra P and Veloso A (1981). Evidence for heteromorphic sex chromosomes in male amphibians (Anura: Leptodactylidae). Cytogenet. Cell Genet. 31: 108-110.

Jeffreys AJ, Wilson V, Wood D, Simons JP, et al. (1980). Linkage of adult alpha- and beta-globin genes in X. laevis and gene duplication by tetraploidization. Cell 21: 555-564.

Jost JP and Hofsteenge J (1992). The repressor MDBP-2 is a number of the histone H1 family that binds preferentially in vitro and in vivo to methylated nonspecific DNA sequences. Proc. Natl. Acad. Sci. U. S. A. 89: 9499-9503.

Kasowski M, Kyriazopoulou-Panagiotopoulou S, Grubert F, Zaugg JB, et al. (2013). Extensive variation in chromatin states across humans. Science 342: 750-752.

Kawamura T (1984). Polyploidy in amphibians. Zool. Sci. 1: 1-5.

Kilpinen H, Waszak SM, Gschwind AR, Raghav SK, et al. (2013). Coordinated effects of sequence variation on DNA binding, chromatin structure, and transcription. Science 342: 744-747.

Knöchel W (1994). Induction of erythropoietin in the amphibian embryo. Ann. NY Acad. Sci. 718: 125-139.

Kobel HR, Du Pasquier L, Fischberg M and Gloor H (1980). Xenopus amieti sp. nov. (Anura: Pipidae) from the Cameroons, another case of tetraploidy. Rev. Suisse Zool. 87: 919-926.

Kumar S and Hedges SB (1998). A molecular timescale for vertebrate evolution. Nature 392: 917-920.

Lee HS and Chen ZJ (2001). Protein-coding genes are epigenetically regulated in Arabidopsis polyploids. Proc. Natl. Acad. Sci. U. S. A. 98: 6753-6758.

Lorenc A and Makalowski W (2003). Transposable elements and vertebrate protein diversity. Genetica 118: 183-191.

Lourenço LB, Recco-Pimentel SM and Cardoso AJ (2000). A second case of multivalent meiotic configurations in diploid species of Anura. Genet. Mol. Biol. 23: 131-133.

Lynch M and Conery JS (2000). The evolutionary fate and consequences of duplicate genes. Science 290: 1151-1155.

Mable BK and Roberts JD (1997). Mitochondrial DNA evolution of tetraploids in the Neobatrachus (Anura: Myobatrachidae). Copeia 1997: 680-689.

Makalowsky W, Mitchell GA and Labuda D (1994). Alu sequences in the coding regions of mRNA: a source of protein variability. Trends Genet. 10: 188-193.

Martino AL and Sinsch U (2002). Speciation by polyploidy in Odontophrynus americanus. J. Zool. 257: 67-81.

Maul GG, Deaven LL, Freed JJ, Campbell GL, et al. (1980). Investigation of the determinants of nuclear pore number. Cytogenet. Cell Genet. 26: 175-190.

Mazik EJu, Kadirova BK and Toktosunov AT (1976). Karyotype patterns in the green toad Bufo viridis in Kirghizia. Zool. Zh. 55: 1740-1742.

Mezquita J, Connor W, Einkfein RJ and Dixon GH (1985). An H1 histone gene from rainbow-trout (Salmo gairdnerii). J. Mol. Evol. 21: 209-219.

Morescalchi A (1973). Amphibia. In: Cytotaxonomy and Vertebrate Evolution (Chiarelli AB and Campana E, eds.). Academic Press, London, New York, 223-348. 
Morescalchi A. (1970). Cytogenetics and the problem of Lissamphibian relationships In: Cytogenetics of Amphibians and Reptiles (Olmo E, ed.). Birkhauser Verlag, Basel, 1-19.

Morescalchi A and Olmo E (1982). Single-copy DNA and vertebrate phylogeny. Cytogenet. Cell Genet. 34: 93-101.

Muller HJ (1925). Why polyploidy is rare in animals than in plants. Ann. Nat. 59: 346-353.

Nekrutenko A and Li WH (2001). Transposable elements are found in a large number of human protein-coding genes. Trends Genet. 17: 619-621.

Ohno S (1970). Evolution by Gene Duplication. Springer-Verlag, Berlin, Heidelberg, New York.

Ohno S (1972). So Much "Junk" DNA in our Genome. In: Evolution of Genetic Systems (HH Smith, ed.). Gordon and Breach, New York, 366-370.

Ohno S (1996). The notion of the Cambrian pananimalia genome. Proc. Natl. Acad. Sci. U. S. A. 93: 8475-8478.

Ohno S (1997). The reason for as well as the consequence of the Cambrian explosion in animal evolution. J. Mol. Evol. 44 (Suppl 1): S23-S27.

Ohno S (1999). Gene duplication and the uniqueness of vertebrate genomes circa 1970-1999. Semin. Cell Dev. Biol. 10: $517-522$.

Ohno S and Beçak ML (1993). Can a protein influence the fate of its own coding sequence? the amino- and carboxylterminal regions of H1 histone. Proc. Natl. Acad. Sci. U. S. A. 90: 7341-7345.

Ovchinnikov I, Rubin A and Swergold GD (2002). Tracing the LINEs of human evolution. Proc. Natl. Acad. Sci. U. S. A. 99: 10522-10527.

Pennisi E (2013a). Evolution heresy? Epigenetics underlies heritable plant traits. Science 341: 1055.

Pennisi E (2013b). Large-scale gene comparisons boost tree of life studies. Science 342: 26-27.

Pikaard CS (2001). Genomic change and gene silencing in polyploids. Trends Genet. 17: 675-677.

Pisanetz EM (1978). On a new polyploid species of toads Bufo danatensis Pisanetz sp. n. from Turkmenia. Dokl. AN. USSR. Ser. B Geol. Geogr. Khim. Biol. 3: 277-282.

Postlethwait JH, Yan YL, Gates MA, Horne S, et al. (1998). Vertebrate genome evolution and the zebrafish gene map. Nat. Genet. 18: 345-349.

Ptacek MB, Gerhardt HC and Sage RD (1994). Speciation of polyploidy in tree frogs: multiple origins of the tetraploidy Hyla versicolor. Evolution 48:898-908.

Rabello MNI (1970). Chromosomal studies in Brazilian Anurans. Caryologia 23: 45-59.

Ralin DB and Selander RK (1979). Evolutionary genetics of diploid-tetraploid species of treefrogs of the genus Hyla. Evolution 33: 595-608.

Rohner N, Jarosz DF, Kowalko JE, Yoshizawa M, et al. (2013). Cryptic variation in morphological evolution: HSP90 as a capacitor for loss of eyes in cavefish. Science 342: 1372-1375.

Ruiz IR and Beçak W (1976). Further studies on polyploid amphibians. V. C-banding in diploid and tetraploid species of Odontophrynus. Chromosoma 54: 69-74.

Ruiz IR and Brison O (1989). Methylation of ribosomal cistrons in diploid and tetraploid Odontophrynus americanus (Amphibia, Anura). Chromosoma 98: 86-92.

Ruiz IR, Bonaldo MF and Beçak W (1980). In situ localization of ribosomal genes in a natural triploid of Odontophrynus. J. Hered. 71: 55-57.

Ruiz IR, Soma M and Beçak W (1981). Nucleolar organizer regions and constitutive heterochromatin in polyploid species of the genus Odontophrynus (Amphibia, Anura). Cytogenet. Cell Genet. 29: 84-98.

Ruiz IR, Ceis JM and Beçak W (1982). Chromosomal evolution in allopatric populations of the Odontophrynus occidentalis group (Amphibia, Anura) from western Argentina. Cytogenet. Cell Genet. 33: 303-311.

Ruiz IR, de Almeida TMB and Beçak W (1984). Active nucleolar-organizer regions in polyploid populations of Odontophrynus americanus (Amphibia, Anura) from South Brazil. Genetica 63: 31-37.

Rutherford SL and Lindquist S (1998). Hsp90 as a capacitor for morphological evolution. Nature 396: 336-342.

Saez FA and Brum-Zorilla N (1966). Karyotype variation in some species of the genus Odontophrynus (Amphibia-Anura). Caryologia 19: 55-63.

Schempp W and Schmid M (1981). Chromosome banding in Amphibia VI. BraU-replication patterns in Anura and demonstration of XX/XY sex chromosomes in Rana esculenta. Chromosoma 83: 697-710.

Schmid M (1978). Chromosome banding in Amphibia. I. Constitutive heterochromatin and nucleolus organizer regions in Bufo and Hyla. Chromosoma 66: 361-388.

Schmid M (1980). Chromosome banding in Amphibia. V. Highly differentiated ZW/ZZ sex chromosomes and exceptional genome size in Pyxicephalus adspersus (Anura, Ranidae). Chromosoma 80: 69-96.

Schmid M and Bachmann K (1981). A frog with highly evolved sex chromosomes. Experientia 37: 243-245.

Schmid M and de Almeida CG (1988). Chromosome banding in Amphibia. XII. Restriction endonuclease banding. 
Chromosoma 96: 283-290.

Schmid M, Haaf T and Schempp W (1985). Chromosome banding in Amphibia. IX. The polyploid karyotypes of Odontophrynus americanus and Ceratophrys ornata (Anura, Leptodactylidae). Chromosoma 91: 172-184.

Schmidtke J, Beçak W and Engel W (1976). The reduction of genic activity in the tetraploid Odontophrynus americanus is not due to loss of ribosomal DNA. Experientia 32: 27-28.

Schwantes AR, Schwantes MLB and Beçak W (1969). Electrophoretic patterns of G-6-PD, 6-PGD and LDH in polyploid amphibians (Ceratophrydidae). Rev. Bras. Pesq. Med. Biol. 2: 41-44.

Schwantes MLB, Schwantes AR and Beçak W (1976). Estudo comparativo de dez enzimas num sistema diploide do gênero Odontophrynus americanus (Ceratophrynidae-Anura). Cienc. Cult. 28 (Suppl): 280-281.

Schwantes MLB, Schwantes AR and Beçak W (1977). Electrophoretic studies on polyploid amphibians. I. 6-phosphogluconate dehydrogenase (6-PGD). Comp. Biochem. Physiol. 56: 393-396.

Skinner MK (2014). A new kind of inheritance. Scient. Am. 311: 35-41.

Soares-Scott MD, Trajtengertz I, Soma M and Beçak ML (1988). C and AgAs bands of the octaploiduntanha frog Ceratophrys dorsata (C. aurita) $(8 \mathrm{n}=104$, Amphibia, Anura). Rev. Bras. Genet. 11: 625-631.

Song K, Lu P, Tang K and Osborn TC (1995). Rapid genome change in synthetic polyploids of Brassica and its implications for polyploid evolution. Proc. Natl. Acad. Sci. U. S. A. 92: 7719-7723.

Tinsley RC, Kobel HR and Fischberg M (1979). The biology and systematics of a new species of Xenopus (Anura: Pipidae) from the highlands of Central Africa. J. Zool. 188: 69-102.

Tymowska J (1991). Polyploidy and Cytogenetic Variation in Frogs of the Genus Xenopus. In: Amphibian Cytogenetics and Evolution (Green DS and Session SK, eds.). Academic Press, San Diego, 259-297.

Tymowska J and Fischberg M (1973). Chromosome complements of the genus Xenopus. Chromosoma 44: 335-342.

Tymowska J, Fischberg M and Tinsley RC (1977). The karyotype of the tetraploid species Xenopus vestitus Laurent (Anura: Pipidae). Cytogenet. Cell Genet. 19: 344-354.

Waddington $\mathrm{CH}$ (1942). Canalization of development and the inheritance of acquired characters. Nature 150: 563-565.

Wasserman AO (1970). Polyploidy in the common tree toad Hyla versicolor Le Conte. Science 167: 385-386.

Weiss RA and Stoye JP (2013). Our viral inheritance. Science 340: 820-821.

Yoder JA, Walsh CP and Bestor TH (1997). Cytosine methylation and the ecology of intragenomic parasites. Trends Genet. 13: 335-340. 